\title{
Gastroretentive floating tablets: An investigation of excipients effect on tablet properties
}

\author{
Shammy Jindal, Kamya Jindal, Ghanshyam Das Gupta, Rajeev Garg, Rajendra Awasthi
}

\begin{abstract}
Present communication was aimed to investigate the effect of excipients on buoyancy and drug release properties from the floating tablets. Gastroretentive floating tablets were developed by the wet granulation method using hydroxypropyl methylcellulose (HPMC K4M), carbopol 934P and carbopol $971 \mathrm{P}$ as a rate controlling polymers and crospovidone as a dissolution enhancer. Sodium bicarbonate and citric acid were used as a gas generating agent. PVP K30 was used as granulating agent. The effect of formulation variables on tablet
\end{abstract}

performance was examined quantitatively based on buoyancy properties, swelling behavior and drug release profiles. The drug release mechanism was investigated using mathematical models. It was found that HPMC/carbopol matrices at 1:1 ratio with crospovidone and sodium bicarbonate gave sustained and better drug release profile upto $24 \mathrm{~h}$ when compared to HPMC or carbopol matrices alone. The mechanism of drug release was found to be anomalous non Fickian.

Keywords: Buoyancy, floating drug delivery, gastroretentive, ofloxacin, swelling index.
Shammy Jindal, Kamya Jindal

Department of Pharmaceutics, Laureate Institute of Pharmacy, Kathog,

Tehsil - Dehra, Distt: Kangra, H.P., India

Ghanshyam Das Gupta

Amar Shaheed Baba Ajit Singh Jujhar Singh Memorial College of Pharmacy, Bela, Ropar, Punjab, India

Rajeev Garg

Department of Pharmaceutics, Amar Shaheed Baba Ajit Singh Jujhar Singh

Memorial College of Pharmacy, Bela, Ropar, Punjab, India

Corresponding author:

Rajendra Awasthi

Department of Pharmaceutics, Laureate Institute of Pharmacy, Kathog,

Tehsil - Dehra, Distt: Kangra, H.P., India

Email: awasthi02@gmail.com

Submitted/Gönderilme: 10.01.2016

Accepted/Kabul: 16.02.2016
Revised/Düzeltme: 14.02 .2016

\section{INTRODUCTION}

Oral route has variable and versatile physiological conditions, which enables development of oral formulations that can selectively release the medicament for optimal therapeutic benefit (1). Conventional drug delivery systems are unable to maintain the drug concentration within the therapeutic range. In case of conventional therapeutic systems, it is often necessary to administer the dosage form several times a day which may result in significant fluctuation in plasma drug concentration. The basic rationale for the development of gastroretentive controlled release drug delivery system is to maintain the drug concentration within the absorption window, reducing the number of administrations and to improve the efficacy of drugs (2). Floating drug delivery systems are less prone to the gastric emptying, resulting in reduced intra and inter-subject variability (3). While the system is floating, the drug is released in a controlled manner from the delivery device. The released drug will have whole surface area of the upper segment of gastrointestinal tract for absorption, and thus the absorption of the drug can be 
enhanced (2). Various gastroretentive dosage forms such as bioadhesive or mucoadhesive systems, dual working systems, high-density systems, expandable systems, floating systems, magnetic systems, and superporous hydrogel systems have been designed to improve the oral bioavailability of drugs by increasing the gastric residence time of dosage form. Considerable attention has been given for the development of a gastroretentive controlled release system using buoyancy mechanism. Floating systems do not bind with gastric mucosal surfaces and reduce the safety problems associated with mucoadhesive systems. Drug delivery systems based on gastroretention mechanisms are not suitable for those drugs which cause gastric lesions such as, non-steroidal antiinflammatory agents (4).

Ofloxacin, poorly soluble drug in alkaline $\mathrm{pH}$ with $\mathrm{pKa}$ of 7.1, exhibits $\mathrm{pH}$ dependent solubility profile in digestive fluid (5). Requirement of acidic $\mathrm{pH}$ for the optimum absorption of ofloxacin reflects its ideal candidature for development of floating drug delivery system. Based on the above facts, the present study was aimed to investigate the effect of various excipients on floating tablet properties which will increase the gastric residence time and release drug in the proximal gastrointestinal region.

\section{MATERIALS AND METHOD}

\section{Materials}

Ofloxacin was received as a gift sample from Wockhardt Ltd., Aurangabad, India. Hydroxypropyl methylcellulose (HPMC K4M) was obtained as a gift sample from Colorcon Asia Pvt Ltd., Goa, India. Crospovidone was obtained as a gift sample from Signet Chemicals, Mumbai, India. Carbopol 934P and 971P were obtained as a gift sample from Lubrizol, Cleveland, USA. Sodium bicarbonate, citric acid, PVP K30, magnesium stearate and talc were purchased from SD Fines, Mumbai, India.

\section{Methods}

\section{Fabrication of floating tablets}

Floating tablets were prepared by wet granulation method. Weighed amounts of various polymers and $400 \mathrm{mg}$ of the drug were thoroughly mixed and passed through sieve no. 40 (Table 1 and Table 2). Wet granulation was done using PVP $\mathrm{K} 30$ solution in isopropyl alcohol $(5 \% \mathrm{w} / \mathrm{v})$. The wet mass was passed through sieve no. 20 and dried in a hot air oven at $40^{\circ} \mathrm{C}$. Dried granules were lubricated using magnesium stearate and talc and compressed into caplet sized tablets using $19.2 \mathrm{X} 9.4 \mathrm{~mm}$ size punch in a rotary tablet press (Rimek Mini Press 1, Karnavati, Ahmedabad, India).

Table 1. Composition of ofloxacin floating tablets.

\begin{tabular}{|c|c|c|c|c|c|c|c|c|c|c|c|}
\hline \multirow{2}{*}{$\begin{array}{l}\text { Composition } \\
\text { (mg/tablet) }\end{array}$} & \multicolumn{11}{|c|}{ Formulation code } \\
\hline & $\mathrm{FH}_{1}$ & $\mathrm{FH}_{2}$ & $\mathrm{FH}_{3}$ & $\mathrm{FH}_{4}$ & $\mathrm{FH}_{5}$ & $\mathrm{FH}_{6}$ & $\mathrm{FH}_{7}$ & $\mathrm{FH}_{8}$ & $\mathrm{FH}_{9}$ & $\mathrm{FH}_{10}$ & $\mathrm{FH}_{11}$ \\
\hline Ofloxacin & 400 & 400 & 400 & 400 & 400 & 400 & 400 & 400 & 400 & 400 & 400 \\
\hline HPMC K4 M & 100 & 150 & 200 & 250 & 200 & 200 & 200 & 200 & 200 & 200 & 200 \\
\hline Sodium bicarbonate & 30 & 30 & 30 & 30 & 50 & 70 & 100 & 30 & 30 & 30 & 30 \\
\hline Crospovidone & 20 & 20 & 20 & 20 & 20 & 20 & 20 & 20 & 20 & 50 & 100 \\
\hline Citric Acid & - & - & - & - & - & - & - & 20 & 40 & - & - \\
\hline
\end{tabular}

Table 2. Composition of ofloxacin floating tablets.

\begin{tabular}{|c|c|c|c|c|c|c|c|c|c|c|c|c|}
\hline \multirow{2}{*}{$\begin{array}{l}\text { Composition } \\
\text { (mg/tablet) }\end{array}$} & \multicolumn{12}{|c|}{ Formulation code } \\
\hline & $\mathrm{FC}_{1}$ & $\mathrm{FC}_{2}$ & $\mathrm{FC}_{3}$ & $\mathrm{FC}_{4}$ & $\mathrm{FC}_{5}$ & $\mathrm{FC}_{6}$ & $\mathrm{FC}_{7}$ & $\mathrm{FC}_{8}$ & $\mathrm{FC}_{9}$ & $\mathrm{FC}_{10}$ & $\mathrm{FC}_{11}$ & $\mathrm{FC}_{12}$ \\
\hline Ofloxacin & 400 & 400 & 400 & 400 & 400 & 400 & 400 & 400 & 400 & 400 & 400 & 400 \\
\hline HРMC K4 M & - & - & - & - & - & - & 100 & 100 & 100 & 100 & 70 & 70 \\
\hline Sodium bicarbonate & - & - & 30 & 30 & 50 & 50 & 30 & 30 & 30 & 30 & 30 & 30 \\
\hline Crospovidone & - & - & - & - & - & - & - & - & 50 & 50 & 50 & 50 \\
\hline Carbopol $934 \mathrm{P}$ & 200 & - & 200 & - & 200 & - & 100 & - & 100 & - & 130 & - \\
\hline Carbopol $971 \mathrm{P}$ & - & 200 & - & 200 & - & 200 & - & 100 & - & 100 & - & 130 \\
\hline
\end{tabular}




\section{Evaluation of floating tablets}

\section{Determination of assay}

Six tablets from each batch were weighed and powdered using a glass mortar and pestle without any material loss. Powder equivalent to the average tablet weight was accurately weighed, transferred into a $100 \mathrm{ml}$ volumetric flask and dissolved in $0.1 \mathrm{~N} \mathrm{HCl}(\mathrm{pH} \mathrm{1.2)}$. For complete drug release, the mixture was agitated for $24 \mathrm{~h}$ at $37 \pm 0.5^{\circ} \mathrm{C}$. After $24 \mathrm{~h}$, the sample was filtered and analyzed using a UV spectrophotometer (UV $3000^{+}$, LabIndia Instruments, Mumbai, India) at $293 \mathrm{~nm}$ after suitable dilution.

\section{Physical characterization}

The fabricated tablets were characterized for weight variation, hardness using Monsanto hardness tester, friability using USP friabilator (EF-2, Electrolab, Mumbai, India) and thickness using a digital screw-gauge micrometer (Mityato, Japan).

\section{Determination of density}

The tablet density was determined by displacement method using benzene as a displacing medium. A plethysmometer was employed to measure the tablet density. The instrument was calibrated using benzene (density $0.8723 \mathrm{~g} / \mathrm{cc}$ ) for its volumetric capacity. Briefly, the benzene was filled up to the mark in capillary of instrument. Subsequently, five tablets of known weight were dropped in the wide mouth of plethysmometer. The system was kept undisturbed for 1 min to displace air by benzene from the tablets pores. The displacement in benzene volume was noted. Knowing the weight and volume occupied by the tablets, density of five tablets was determined (6).

\section{Determination of buoyancy properties}

The time taken by the tablet to emerge on surface of the medium (floating lag time) and duration of the tablet to constantly remain on surface of the medium (total floating time) were investigated using USP 24 type II dissolution apparatus at $37 \pm 0.5^{\circ} \mathrm{C}$ in $900 \mathrm{ml}$ of $0.1 \mathrm{~N} \mathrm{HCl}$. Total six measurements were taken from each batch $(n=6)(7)$.

\section{Determination of swelling index}

Ofloxacin floating tablets were weighed individually $\left(\mathrm{W}_{0}\right)$ and placed in $900 \mathrm{ml}$ of dissolution medium $(0.1 \mathrm{~N} \mathrm{HCl})$. The temperature was maintained at $37 \pm 0.5^{\circ} \mathrm{C}$. On saturation, the tablets were removed and swollen tablet weight $\left(\mathrm{W}_{\mathrm{t}}\right)$ was determined. The percentage swelling index was calculated by (8):

$$
\text { Swelling index }(\%)=\frac{W_{t}-W_{0}}{W_{0}} \times 100
$$

\section{In vitro release study}

The release of ofloxacin from floating tablets was studied using USP dissolution apparatus II. The release studies were carried out in $900 \mathrm{ml}$ of $0.1 \mathrm{~N} \mathrm{HCl}(\mathrm{pH} 1.2)$ at $100 \mathrm{rpm}$. The temperature was maintained at $37 \pm 0.5^{\circ} \mathrm{C}$. Aliquots $(5 \mathrm{ml})$ were withdrawn at predetermined time intervals of every $1 \mathrm{~h}$ for the first $4 \mathrm{~h}$ followed by every $2 \mathrm{~h}$ interval till 12 th $\mathrm{h}$ and then at every $4 \mathrm{~h}$ interval till 24 th $\mathrm{h}$. The sink condition was maintained by replacing an equivalent amount of dissolution medium after each sampling. The samples were analyzed using a UV spectrophotometer (UV $3000^{+}$, LabIndia Instruments, Mumbai, India) at $293 \mathrm{~nm}$. The sampling was done in triplicate from each batch (9).

\section{Analysis of drug release kinetics}

To study the drug release kinetics, the dissolution data were plotted in various kinetic models: zero order as the cumulative amount of drug released against time, first order as the log cumulative percentage of drug remaining against time. The drug release mechanism was determined using Higuchi's model as a cumulative percentage of drug released against the square root of time (10) and Korsmeyer model as a log percentage of drug released against log time. The in vitro drug release data were statistically analyzed by two-way analysis of variance (ANOVA). The $\mathrm{p}$ value of $<0.0001$ was considered as statistically significant.

\section{RESULTS AND DISCUSSIONS}

Assay

The drug content in all the formulations was in the range of 99.11 to $101.23 \%$. This ensured the uniformity of drug within the tablet.

\section{Physical characterization}

Weight variation data indicates no significant difference in individual tablet weight from the average weight. Tablet hardness was observed within the range of $3.1 \pm 0.134$ to $4.2 \pm 0.152 \mathrm{~kg} / \mathrm{cm}^{2}$. Friability of all the formulations was below $1 \%$, which indicates good mechanical strength of the tablets (Table 3). 
Table 3. Physical properties of ofloxacin floating tablets.

\begin{tabular}{|c|c|c|c|c|c|c|c|c|}
\hline $\begin{array}{l}\text { Formulation } \\
\text { code }\end{array}$ & $\begin{array}{l}\text { Density } \\
\left(\mathrm{g} / \mathrm{cm}^{3}\right)\end{array}$ & $\begin{array}{l}\text { Floating } \\
\text { lag time } \\
\text { (sec) }\end{array}$ & $\begin{array}{c}\text { Floating } \\
\text { Duration } \\
\text { (h) }\end{array}$ & $\begin{array}{l}\text { Thickness } \\
\text { (mm) }\end{array}$ & $\begin{array}{c}\text { Weight } \\
\text { (mg) }\end{array}$ & $\begin{array}{c}\text { Friability } \\
(\%)\end{array}$ & $\begin{array}{c}\text { Hardness } \\
\left(\mathrm{kg} / \mathrm{cm}^{2}\right)\end{array}$ & $\begin{array}{c}\text { Assay } \\
(\%)\end{array}$ \\
\hline $\mathrm{FH}_{1}$ & $0.717 \pm 0.086$ & $35.3 \pm 3.6$ & $12.0 \pm 2.5$ & $5.124 \pm 0.008$ & $560.1 \pm 0.912$ & 0.75 & $3.5 \pm 0.133$ & 99.23 \\
\hline $\mathrm{FH}_{2}$ & $0.780 \pm 0.099$ & $43.0 \pm 5.0$ & $12.0 \pm 3.5$ & $5.278 \pm 0.018$ & $612.2 \pm 0.230$ & 0.38 & $3.5 \pm 0.095$ & 99.11 \\
\hline $\mathrm{FH}_{3}$ & $0.753 \pm 0.046$ & $39.2 \pm 4.4$ & $12.0 \pm 2.6$ & $5.424 \pm 0.006$ & $662.1 \pm 1.821$ & 0.64 & $3.0 \pm 0.125$ & 99.44 \\
\hline $\mathrm{FH}_{4}$ & $0.812 \pm 0.024$ & $48.1 \pm 6.7$ & $16.0 \pm 1.7$ & $5.672 \pm 0.005$ & $715.8 \pm 3.654$ & 0.67 & $3.6 \pm 0.113$ & 99.17 \\
\hline $\mathrm{FH}_{5}$ & $0.686 \pm 0.087$ & $32.9 \pm 4.1$ & $20.0 \pm 1.5$ & $5.462 \pm 0.014$ & $665.1 \pm 2.734$ & 0.49 & $4.1 \pm 0.109$ & 98.17 \\
\hline $\mathrm{FH}_{6}$ & $0.734 \pm 0.073$ & $25.6 \pm 3.2$ & $20.0 \pm 1.7$ & $6.198 \pm 0.067$ & $755.2 \pm 4.167$ & 0.45 & $3.8 \pm 0.165$ & 99.34 \\
\hline $\mathrm{FH}_{7}$ & $0.769 \pm 0.101$ & $12.0 \pm 2.0$ & $20.0 \pm 4.0$ & $6.377 \pm 0.081$ & $785.8 \pm 1.891$ & 0.56 & $3.2 \pm 0.093$ & 99.20 \\
\hline $\mathrm{FH}_{8}$ & $0.651 \pm 0.090$ & $15.7 \pm 1.9$ & $12.0 \pm 3.5$ & $5.367 \pm 0.011$ & $632.3 \pm 2.781$ & 0.54 & $4.2 \pm 0.152$ & 99.50 \\
\hline $\mathrm{FH}_{9}$ & $0.690 \pm 0.085$ & $17.0 \pm 2.0$ & $12.0 \pm 2.0$ & $6.016 \pm 0.028$ & $735.7 \pm 3.254$ & 0.63 & $4.0 \pm 0.096$ & 99.42 \\
\hline $\mathrm{FH}_{10}$ & $0.816 \pm 0.034$ & $39.2 \pm 4.8$ & $16.0 \pm 3.2$ & $5.987 \pm 0.033$ & $695.6 \pm 2.672$ & 0.69 & $3.6 \pm 0.126$ & 99.99 \\
\hline $\mathrm{FH}_{11}$ & $0.844 \pm 0.029$ & $45.6 \pm 6.3$ & $12.0 \pm 2.0$ & $6.156 \pm 0.021$ & $745.4 \pm 3.123$ & 0.81 & $3.1 \pm 0.134$ & 101.21 \\
\hline $\mathrm{FC}_{1}$ & $1.321 \pm 0.151$ & $>2700$ & - & $5.209 \pm 0.041$ & $612.9 \pm 4.176$ & 0.54 & $3.6 \pm 0.101$ & 99.79 \\
\hline $\mathrm{FC}_{2}$ & $1.335 \pm 0.101$ & $>2700$ & - & $5.267 \pm 0.034$ & $612.2 \pm 3.654$ & 0.68 & $3.3 \pm 0.091$ & 101.10 \\
\hline $\mathrm{FC}_{3}$ & $0.983 \pm 0.96$ & $360.0 \pm 30.0$ & $24.0 \pm 0.6$ & $5.367 \pm 0.069$ & $642.6 \pm 2.176$ & 0.45 & $3.6 \pm 0.138$ & 99.57 \\
\hline $\mathrm{FC}_{4}$ & $0.971 \pm 0.045$ & $420.0 \pm 50.0$ & $24.0 \pm 1.6$ & $5.398 \pm 0.081$ & $642.4 \pm 3.271$ & 0.31 & $4.1 \pm 0.104$ & 99.23 \\
\hline $\mathrm{FC}_{5}$ & $0.936 \pm 0.181$ & $120.0 \pm 30.0$ & $24.0 \pm 1.8$ & $5.467 \pm 0.014$ & $665.8 \pm 1.832$ & 0.88 & $3.3 \pm 0.161$ & 99.14 \\
\hline $\mathrm{FC}_{6}$ & $0.942 \pm 0.086$ & $130.0 \pm 30.0$ & $24.0 \pm 1.3$ & $5.492 \pm 0.024$ & $665.3 \pm 4.427$ & 0.73 & $4.2 \pm 0.144$ & 99.34 \\
\hline $\mathrm{FC}_{7}$ & $0.894 \pm 0.093$ & $60.0 \pm 40.0$ & $24.0 \pm 0.5$ & $5.376 \pm 0.038$ & $642.1 \pm 4.246$ & 0.48 & $3.9 \pm 0.091$ & 99.29 \\
\hline $\mathrm{FC}_{8}$ & $0.910 \pm 0.036$ & $68.0 \pm 10.2$ & $24.0 \pm 1.1$ & $5.362 \pm 0.061$ & $642.9 \pm 3.551$ & 0.63 & $3.8 \pm 0.141$ & 99.92 \\
\hline $\mathrm{FC}_{9}$ & $0.875 \pm 0.071$ & $55.2 \pm 8.4$ & $24.0 \pm 1.0$ & $5.856 \pm 0.074$ & $695.3 \pm 2.731$ & 0.59 & $3.1 \pm 0.069$ & 99.88 \\
\hline $\mathrm{FC}_{10}$ & $0.893 \pm 0.097$ & $51.0 \pm 5.4$ & $24.0 \pm 0.4$ & $5.826 \pm 0.018$ & $695.3 \pm 1.105$ & 0.71 & $3.4 \pm 0.121$ & 101.23 \\
\hline $\mathrm{FC}_{11}$ & $0.991 \pm 0.102$ & $70.8 \pm 6.6$ & $24.0 \pm 0.5$ & $6.163 \pm 0.009$ & $745.3 \pm 1.90$ & 0.77 & $3.7 \pm 0.113$ & 98.99 \\
\hline $\mathrm{FC}_{12}$ & $0.989 \pm 0.049$ & $74.6 \pm 5.4$ & $24.0 \pm 1.0$ & $6.198 \pm 0.015$ & $745.4 \pm 3.241$ & 0.59 & $3.6 \pm 0.133$ & 99.78 \\
\hline
\end{tabular}

Data represents mean $\pm S D(n=6)$

\section{Tablet density}

Apparent tablet density was found to be in the range of $0.651 \pm 0.090$ to $0.989 \pm 0.049 \mathrm{~g} / \mathrm{cm}^{3}$, except formulation $\mathrm{FC}_{1}$ and $\mathrm{FC}_{2}$. High densities of formulation $\mathrm{FC}_{1}$ and $\mathrm{FC}_{2}$ might be due to the fact that carbopol is less porous in nature and thus the tablet had a higher bulk density than other polymers used. The density of tablets was decreased by an increased amount of HPMC, crospovidone and sodium bicarbonate. The variation in tablet density might be due to the difference in the porosity of polymers used.

\section{Buoyancy properties}

All the formulations (except formulation $\mathrm{FC}_{1}$ and $\mathrm{FC}_{2}$ ) had a short floating lag time due to the presence of sodium bicarbonate. Formulation $\mathrm{FC}_{1}$ and $\mathrm{FC}_{2}$ had more than 45 min floating lag time and showed practically no floating behavior. An increase in the sodium bicarbonate amount from $0 \mathrm{mg}$ to $30 \mathrm{mg}$ in carbopol matrices reduced the floating lag time. Decrease in floating lag time was observed with the incorporation of HPMC K4M and crospovidone to the carbopol matrices (formulation $\mathrm{FC}_{7}$ to $\mathrm{FC}_{12}$ ). After an initial floating lag time, all the tablets were floating uniformly for a prolonged period of time. This may be due to the entrapment of carbon dioxide gas within the tablet gel matrix formed by the hydration of HPMC, carbopol and crospovidone. Higher buoyancy duration of carbopol containing tablets may be due to the less swelling of carbopol and entrapment of $\mathrm{CO}_{2}$ gas in the carbopol gel layer. More floating lag time of carbopol containing tablets may be due to the higher density of carbopol.

\section{Swelling index}

The swelling nature of polymer affects the dissolution behavior. Thus, in the present investigation, the swelling behavior of tablets was determined using water uptake approach. The 
polymer in tablet matrix undergoes simultaneously swelling, dissolution, and diffusion into the bulk medium, resulting in reduction of strength and erosion of the matrix $(11,12)$. In the present study, complete swelling was achieved at the end of 8 $\mathrm{h}$ (Figure $1 \mathrm{~A}$ and Figure $1 \mathrm{~B}$ ). An increase in tablet swelling was observed with an increase in HPMC concentration (formulation $\mathrm{FH}_{1}$ to $\mathrm{FH}_{4}$ ). Significant increase in swelling of the tablet was observed with an addition of crosspovidone. When the concentration of crospovidone was increased from $20 \mathrm{mg}$ (formulation $\mathrm{FH}_{3}$ ) to $100 \mathrm{mg}$ (formulation $\mathrm{FH}_{11}$ ), the tablet swelling was increased from $216.89 \%$ to $259.34 \%$. It was due to the controlled and high swelling of crospovidone in the presence of water soluble hydrophilic polymer. Carbopol matrices showed limited changes in the percentage swelling when compared to HPMC matrices. Pure carbopol matrices, formulations $\mathrm{FC}_{1}$ and $\mathrm{FC}_{2}$ showed $52.76 \%$ and $53.87 \%$ swelling, respectively. Addition of sodium bicarbonate in carbopol matrices increased swelling of tablets. This might be due to the entrapment of $\mathrm{CO}_{2}$ gas in the carbopol gel layer. Carbopol/HPMC matrices containing sodium bicarbonate showed an increased swelling as compared to the formulations containing pure carbopol. Such swelling behavior could be due to the hydrophilic nature of the HPMC and entrapment of gas within the gel matrix. With the addition of crospovidone in Carbopol/HPMC matrices (formulation $\mathrm{FC}_{9}$ and $\mathrm{FC}_{10}$ ), higher percentage swelling was observed. Further increase in Carbopol concentration in Carbopol/HPMC matrices decreased the percentage swelling due to decrease in hydrophilic polymer (HPMC) concentration.
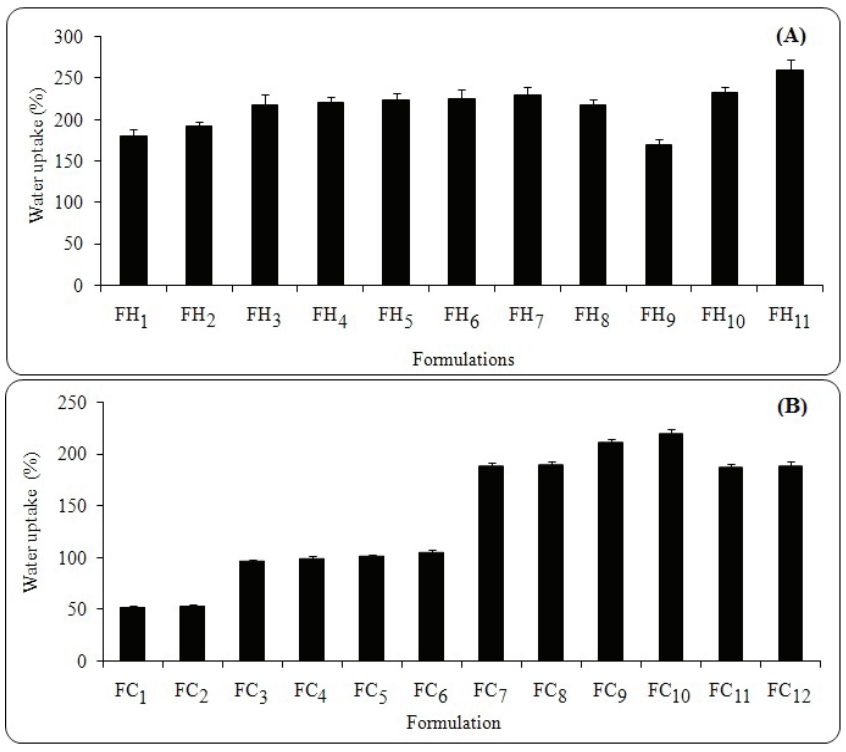

Figure 1. Effect of various processing parameters on swelling behavior of tablets after $8 \mathrm{~h}$, formulations $\mathrm{FH}_{1}-\mathrm{FH}_{11}(\mathrm{~A})$ and formulations $\mathrm{FC}_{1}-\mathrm{FC}_{12}(\mathrm{~B})$.

\section{In vitro release study}

Ideally, an extended-release tablet should release the the drug in a predetermined and reproducible manner. In vitro dissolution studies were aimed to investigate the effect of gas generating agent and polymer type and concentration on the release behavior of ofloxacin from the floating tablets.

\section{Effect of HPMC concentration on drug release}

Tablets prepared using HPMC K4M alone showed sustained drug release for 12 to $20 \mathrm{~h}$. The drug release from tablets containing HPMC K4M (100 mg) showed 99.97\% drug release at the end of $12 \mathrm{~h}$. The more sustaining effect was observed with an increase in HPMC K4M concentration from $100 \mathrm{mg}$ to $250 \mathrm{mg}$. Percentage cumulative drug release after $4 \mathrm{~h}$ was found to be $53.2 \%, 50.32 \%, 42.53 \%$ and $36.66 \%$ from formulation $\mathrm{FH}_{1}, \mathrm{FH}_{2}, \mathrm{FH}_{3}$ and $\mathrm{FH}_{4}$, respectively (Figure 2). This effect on drug release profile might be due the increase in resistance of gel layer caused by greater intimate contact between the particles of HPMC which results in decreased mobility of insoluble drug particles in swollen matrices, which led to decreased release (13).

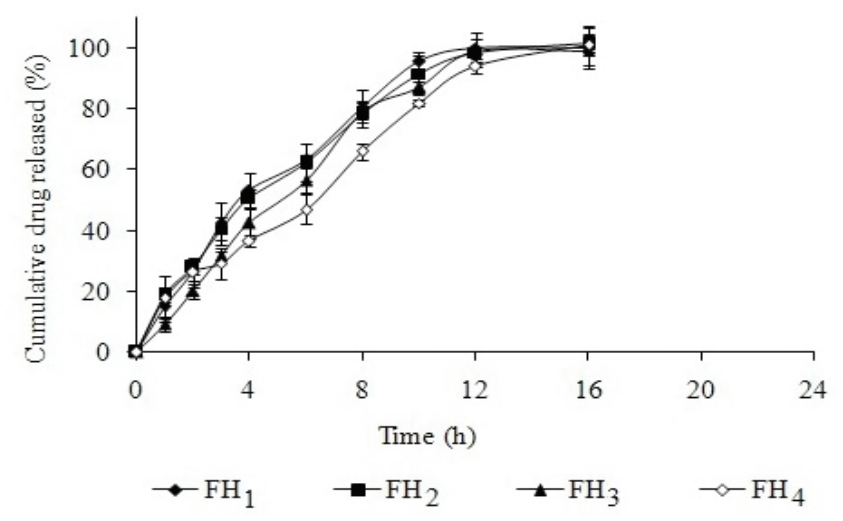

Figure 2. The effect of HPMC concentration on drug release from HPMC matrices in $0.1 \mathrm{~N} \mathrm{HCl}, \mathrm{pH} 1.2$ at $37^{\circ} \mathrm{C}$ (mean $\pm \mathrm{SD}, \mathrm{n}=3$ ).

\section{Effect of effervescent agents on drug release}

Sodium bicarbonate and citric acid act as effervescent agents that generate $\mathrm{CO}_{2}$ gas when the tablet comes in contact with an aqueous acidic medium. $\mathrm{CO}_{2}$ gas entrapped into the matrices of water soluble polymers and leads to up word movement of tablets thus tablets floats on acidic medium. As the concentration of sodium bicarbonate increased in formulations $\mathrm{FH}_{3}(30 \mathrm{mg}), \mathrm{FH}_{5}(50 \mathrm{mg}), \mathrm{FH}_{6}(70 \mathrm{mg})$ and $\mathrm{FH}_{7}(100 \mathrm{mg})$, the drug release was found to be decreased at the end of $4 \mathrm{~h}$ (Figure $3 \mathrm{~A}$ ). This effect may be due to the $\mathrm{pH}$ dependent solubility profile of ofloxacin. Ofloxacin is more soluble in acidic medium as compared to alkaline medium. 
Increase in concentration of sodium bicarbonate created an alkaline micro-environment, thus more sustained effect was observed. The results are in concordance with the finding of earlier researchers (14). Effect of citric acid is shown in figure 3 (B). An increase in the concentration of citric acid led to the more burst drug release as compared to the formulation without citric acid. Formulations containing citric acid $\mathrm{FH}_{8}$ $(20 \mathrm{mg})$ and $\mathrm{FH}_{9}(40 \mathrm{mg})$ showed faster drug release at $4 \mathrm{~h}$ that was $53.17 \%$ and $56.81 \%$, respectively compared to $\mathrm{FH}_{3}(0$ $\mathrm{mg}) 42.53 \%$. But, citric acid led to the dimensional stability problems of tablets, thus citric acid was not use in the further formulations.

The addition of $30 \mathrm{mg}$ of sodium bicarbonate to pure carbopol matrices led to increase in the floating properties of the tablets and increase in the drug release. As the concentration of sodium bicarbonate increased from $0 \mathrm{mg}\left(\mathrm{FC}_{1}\right.$ and $\left.\mathrm{FC}_{2}\right)$ to $30 \mathrm{mg}\left(\mathrm{FC}_{3}\right.$ and $\left.\mathrm{FC}_{4}\right)$, the percent cumulative drug release was increased from $41.75 \%$ and $41.53 \%$ to $63.33 \%$ and 63.02 , respectively at the end of $12 \mathrm{~h}$. Further increase in sodium bicarbonate concentration led to decrease the percentage cumulative drug release. This might be due to the alkaline micro-environment caused by the increased concentration of sodium bicarbonate. At the end of $12 \mathrm{~h}$ the drug release was found to be $59.54 \%$ and $58.93 \%$ for the formulation $\mathrm{FC}_{5}$ and $\mathrm{FC}_{6}$, respectively (Figure $3 \mathrm{C}$ ).
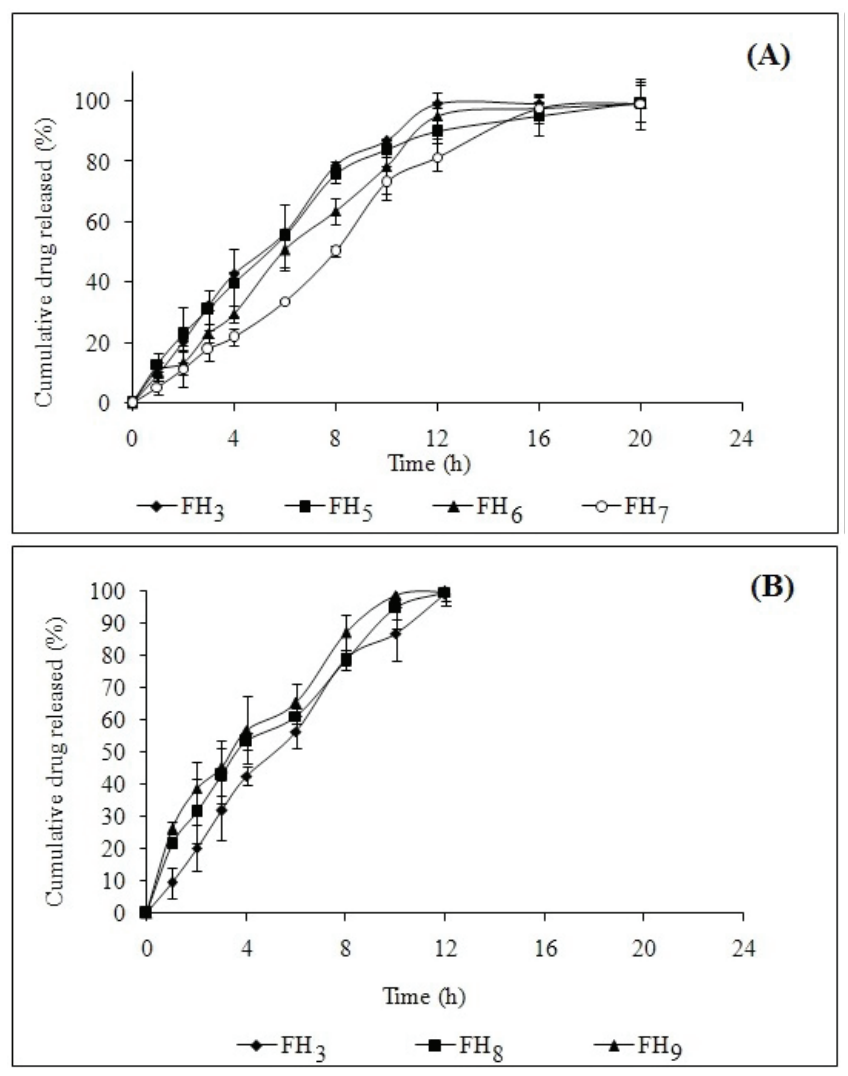

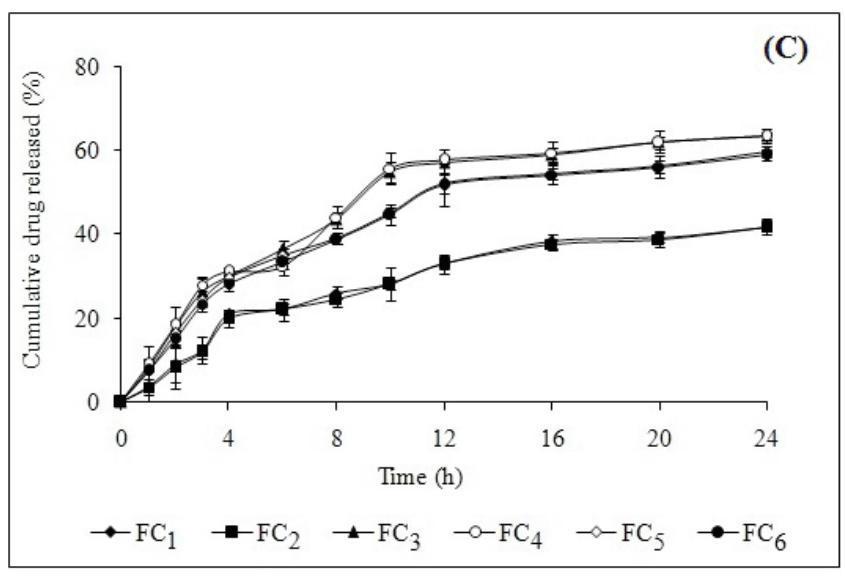

Figure 3. The effect of effervescent agents concentration on drug release in $0.1 \mathrm{~N} \mathrm{HCl}, \mathrm{pH} 1.2$ at $37^{\circ} \mathrm{C}($ mean $\pm \mathrm{SD}, \mathrm{n}=3)$. Effect of sodium bicarbonate concentration on drug release from HPMC matrices (A), effect of citric acid on drug release from HPMC matrices (B), effect of sodium bicarbonate concentration on drug release from carbopol matrices (C).

\section{Effect of crospovidone on drug release}

Crospovidone is a superdisintegrant, when comes into contact with an aqueous medium swell immediately to at least twice its original volume. Carbopol and HPMC K100M were used simultaneously to form a gel network due to which the swollen mass of crospovidone restrained in the tablet and the tablet does not disintegrate. The effect of crospovidone on drug release profile is presented in figure 4 (A). It is evident that as the concentration of crospovidone increased from $20 \mathrm{mg}\left(\mathrm{FH}_{3}\right)$ to $50 \mathrm{mg}\left(\mathrm{FH}_{10}\right)$, the percent cumulative drug released was increased from $31.83 \%$ to $46.65 \%$ at the end of 4 h. In case of formulation containing $100 \mathrm{mg}$ of crospovidone $\left(\mathrm{FH}_{11}\right)$, the percent cumulative drug release was found to be $53.56 \%$ at the end of $4 \mathrm{~h}$. As the concentration of crospovidone increased, the water uptake capacity of the formulation increased which could have contributed to increase in the drug release from the formulation and also leads to the dimensional instability of the tablet. Based on such findings, less than $50 \mathrm{mg}$ of crospovidone is suggested for the formulation of HPMC based floating tablet.

Crospovidone improved the drug release profile from the carbopol matrix due to its swelling properties. The addition of $50 \mathrm{mg}$ crospovidone to the formulations $\mathrm{FC}_{9}$ and $\mathrm{FC}_{10}$ the drug release was increased as compared to the formulations $\mathrm{FC}_{7}$ and $\mathrm{FC}_{8}$ and it was found to be $99.92 \%$ and $99.95 \%$ at the end of $24 \mathrm{~h}$ (Figure $4 \mathrm{~B}$ ). 

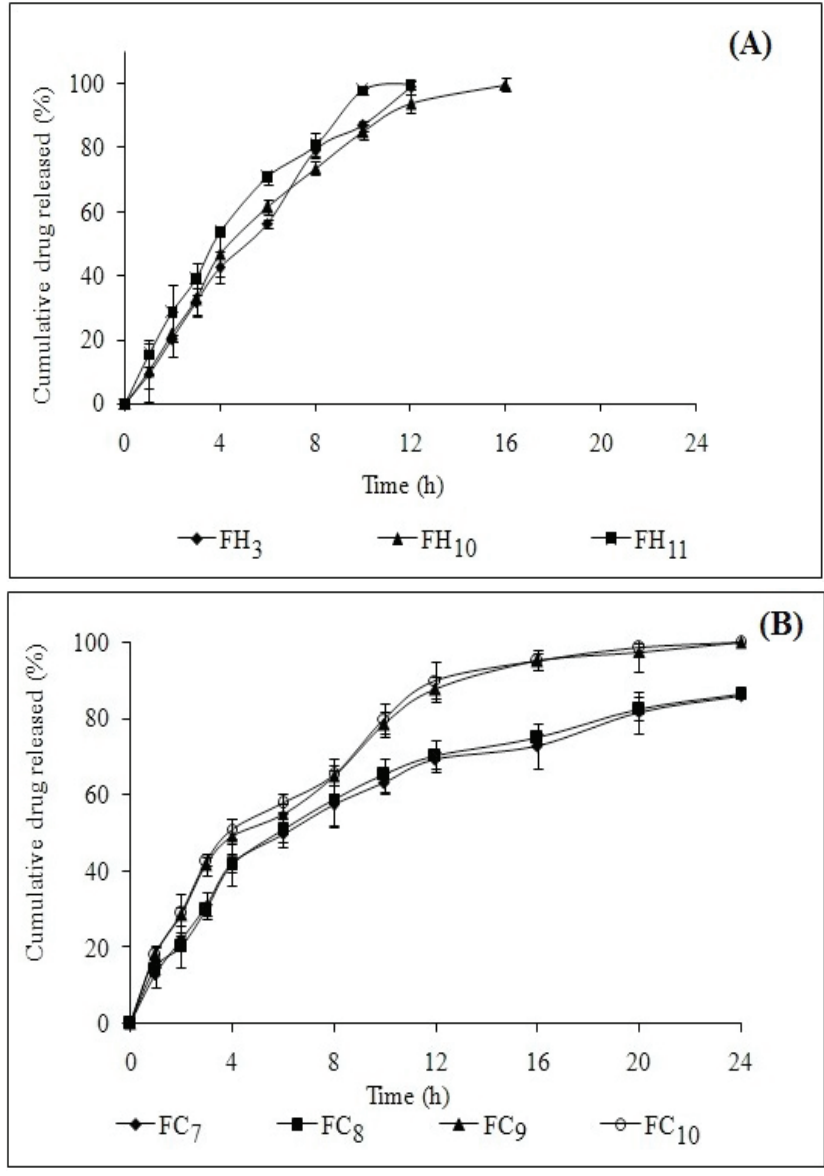

Figure 4. Effect of crospovidone concentration on drug release in $0.1 \mathrm{~N} \mathrm{HCl}, \mathrm{pH} 1.2$ at $37^{\circ} \mathrm{C}($ mean $\pm \mathrm{SD}, \mathrm{n}=3)$. Effect of crospovidone concentration on drug release from HPMC matrices (A), effect of crospovidone concentration on drug release from carbopol matrice (B).

\section{Effect of carbopol on drug release}

In order to sustain the drug release for $24 \mathrm{~h}$, carbopol was added due to its high viscosity and swelling properties. Pure carbopol matrices (formulation $\mathrm{FC}_{1}$ and $\mathrm{FC}_{2}$ ) sustained the drug release for $24 \mathrm{~h}$ and cumulative percentage drug release at the end of $24 \mathrm{~h}$ was found to be $41.75 \%\left(\mathrm{FC}_{1}\right)$ and $41.53 \%$ $\left(\mathrm{FC}_{2}\right)$.

Increase in carbopol concentration in carbopol-HPMC combination matrices leads to decrease in drug release (Figure 5). The cumulative percentage drug release was found to be $87.39 \%\left(\mathrm{FC}_{11}\right)$ and $89.08 \%\left(\mathrm{FC}_{12}\right)$ as compared to $99.92 \%\left(\mathrm{FC}_{9}\right)$ and $99.95 \%\left(\mathrm{FC}_{10}\right)$ after $24 \mathrm{~h}$ due to the formation of gel layer, which retarded the release of the drug. Change in carbopol grade did not affect the cumulative percentage drug release.

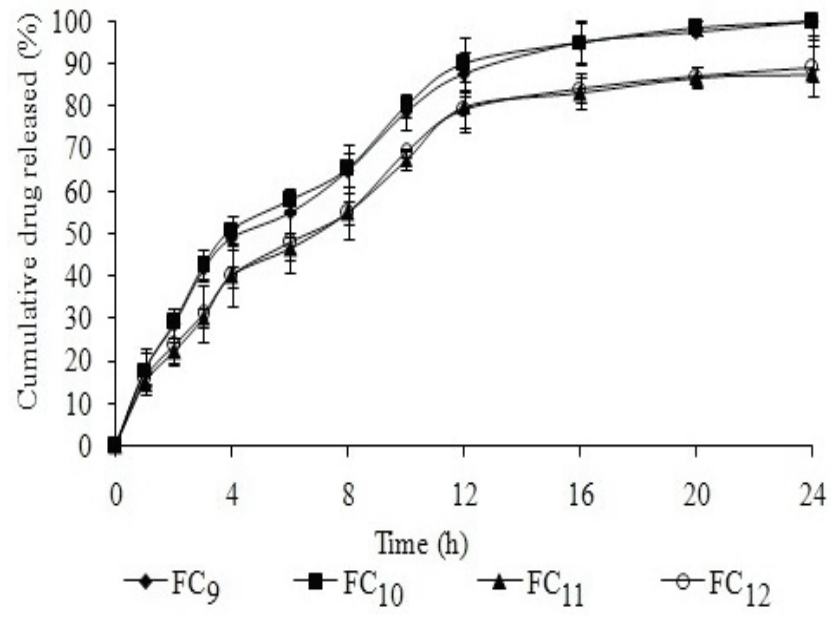

Figure 5. The effect of carbopol concentration on drug release in $0.1 \mathrm{~N} \mathrm{HCl}, \mathrm{pH} 1.2$ at $37^{\circ} \mathrm{C}($ mean $\pm \mathrm{SD}, \mathrm{n}=3)$.

\section{Effect of carbopol-HPMC combination on drug release}

It was found that, alone carbopol retarded the drug release due to early disappearance of $\mathrm{CO}_{2}$ bubbles. But, in case of formulations containing Carbopol and HPMC combination resulted in swelling, no disappearance $\mathrm{CO}_{2}$ bubbles and prolonged drug release due to the hydrophilic nature of HPMC was observed. In formulation $\mathrm{FC}_{7}$ and $\mathrm{FC}_{8}$ carbopol and HPMC K4M were used in 1:1 ratio. The cumulative percentage drug release was increased in formulation $\mathrm{FC}_{7}$ (85.71\%), $\mathrm{FC}_{8}(86.43 \%)$ as compared to $\mathrm{FC}_{3}(41.75 \%)$ and $\mathrm{FC}_{4}(41.53 \%)$ at the end of $24 \mathrm{~h}$ (Figure 6).

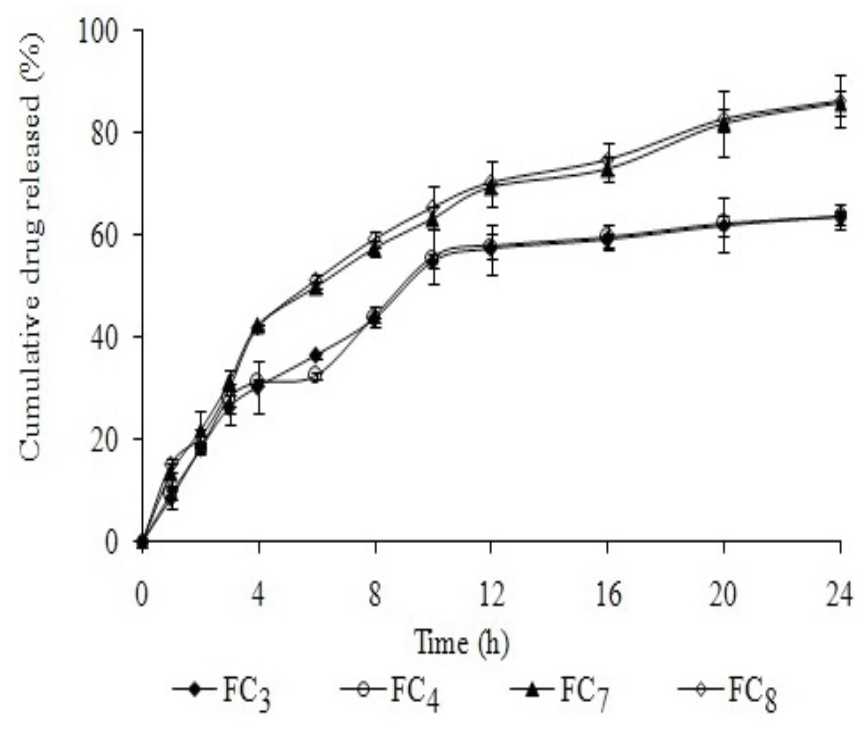

Figure 6. The effect of carbopol/HPMC combination on drug release in $0.1 \mathrm{~N} \mathrm{HCl}, \mathrm{pH} 1.2$ at $37^{\circ} \mathrm{C}($ mean $\pm \mathrm{SD}, \mathrm{n}=3)$. 


\section{Drug release kinetics}

Three major rate controlling mechanisms for controlled or sustained release formulations are diffusion, swelling and disintegration/ erosion (2). The drug release from the polymeric system is generally followed by the diffusion process and best described by Fickian diffusion mechanism. But, in case of formulations containing polymers having swelling property, relaxation of polymer chains, ambition of water, causing the polymers to swell and changing them from initial glassy to rubbery state can also describe the drug release behavior (15).

The drug dissolution from pharmaceutical dosage forms that do not disaggregate and release the drug slowly can be described by zero order kinetics.

$$
\mathrm{Q}_{1}=\mathrm{Q}_{0}+\mathrm{K}_{0} \mathrm{t}
$$

where $Q_{1}$ is the amount of the drug dissolved in time $t, Q_{0}$ is the initial amount of drug in solution, $\mathrm{K}_{0}$ is the zero-order rate constant expressed in units of concentration/time and $t$ is the time in $\mathrm{h}$. A graph of concentration against time would yield a straight line with a slope equal to $\mathrm{K}_{0}$ and intercept the origin of the axes.

The first order model is used to describe absorption and elimination of drugs. Following equation expresses this model:

$$
\log \mathrm{Q}_{1}=\log \mathrm{Q}_{0}+\left(\mathrm{K}_{1} \mathrm{t} / 2.303\right)
$$

where $Q_{1}$ is the amount of drug released in time $t, Q_{0}$ is the initial amount of drug in the solution and $K_{1}$ is the first order release constant. In case of drug release following first order kinetics, a plot of the logarithm of drug released against time will be linear.

Higuchi developed several models to study the release of water soluble and low soluble drugs incorporating in semi solid and or solid matrices. The Higuchi's model is expressed as (16).

$$
\mathrm{F}_{\mathrm{t}}=\mathrm{K}_{\mathrm{H}} \mathrm{t}^{1 / 2}
$$

where $\mathrm{K}_{\mathrm{H}}$ is the Higuchi's dissolution constant reflecting the design variables of the system and $t$ is the time in h. Hence, the drug release rate is proportional to the reciprocal of the square root of time. Higuchi described drug release as a diffusion process based on the Fick's law, square root time dependent.

To evaluate the mechanism of drug release from ofloxacin floating tablets, the dissolution data were plotted according to the Korsmeyer equation as log cumulative percentage of drug released against log time, and the exponent $\mathrm{n}$ was calculated through the slope of the straight line.

$$
M_{t} / M_{\infty}=a t^{n}
$$

where $M_{t} / M_{\infty}$ is the fractional solute release, $t$ is the release time, $\mathrm{K}$ is a kinetic constant characteristic of the drug/ polymer system, and $\mathrm{n}$ is an exponent that characterizes the release mechanism. If the value of $\mathrm{n}$ is less than or equal to 0.45 , it corresponds to a Fickian diffusion mechanism, if the value is greater than 0.45 and less than 0.89 , it corresponds to non-Fickian transport, if the value is equal to 0.89 , it corresponds to Case II (relaxational) transport, and if it is above 0.89 the release mechanism is super case II transport.

In the present investigation, with an increase in HPMC concentration in HPMC matrices, the drug release followed zero order release profile (formulation $\mathrm{FH}_{2}-\mathrm{FH}_{4}$ ). When the higher correlation coefficient values are considered, the released data from the most HPMC based formulations seem to fit better with zero order and Korsmeyer model. The released data from carbopol based formulations seem to fit better with first order and Higuchi model. Further, the n values obtained from the Korsmeyer kinetic model suggested that the drug release mechanism was shifted from Fickian to nonFickian direction with an increased amount of gas generating agent. These findings are not in the support of Khan et al. (17). In case of tablets containing HPMC alone at the highest concentration of gas generating agent (formulation $\mathrm{FH}_{7}$ ), the n value obtained from Korsmeyer kinetic model was 1.0408, which indicated super case II transport mechanism of drug release. In HPMC-Carbopol matrices, the best fit with the highest determination $\mathrm{r}^{2}$ coefficients was shown by both the first order and Higuchi models which indicate the drug release via diffusion mechanism. The $\mathrm{n}$ values of 0.5421 to 0.7438 indicated that the drug release mechanism was nonFickian or anomalous diffusion. The kinetic data obtained from in vitro release study are presented in table 4. 
Table 4. Kinetics of in vitro release data from floating tablets of ofloxacin.

\begin{tabular}{|c|c|c|c|c|c|}
\hline \multirow{2}{*}{ Formulation Code } & \multirow{2}{*}{ Zero order $\left(\mathbf{r}^{2}\right)$} & \multirow{2}{*}{ First order $\left(\mathbf{r}^{2}\right)$} & \multirow{2}{*}{$\begin{array}{l}\text { Higuchi Model } \\
\qquad\left(\mathbf{r}^{2}\right)\end{array}$} & \multicolumn{2}{|c|}{ Korsmeyer model } \\
\hline & & & & $\mathbf{n}$ & $\mathbf{r}^{2}$ \\
\hline $\mathrm{FH}_{1}$ & 0.8872 & 0.9055 & 0.9647 & 0.7094 & 0.9683 \\
\hline $\mathrm{FH}_{2}$ & 0.9116 & 0.8930 & 0.9785 & 0.6488 & 0.9866 \\
\hline $\mathrm{FH}_{3}$ & 0.9219 & 0.8926 & 0.9516 & 0.8835 & 0.9739 \\
\hline $\mathrm{FH}_{4}$ & 0.9633 & 0.8897 & 0.9568 & 0.6738 & 0.9761 \\
\hline $\mathrm{FH}_{5}$ & 0.8782 & 0.9884 & 0.9597 & 0.7231 & 0.9734 \\
\hline $\mathrm{FH}_{6}$ & 0.9068 & 0.9168 & 0.9377 & 0.8655 & 0.9657 \\
\hline $\mathrm{FH}_{7}$ & 0.9532 & 0.8549 & 0.9228 & 1.0408 & 0.9877 \\
\hline $\mathrm{FH}_{8}$ & 0.8928 & 0.8926 & 0.9742 & 0.5979 & 0.9840 \\
\hline $\mathrm{FH}_{9}$ & 0.9334 & 0.8281 & 0.9675 & 0.5229 & 0.9766 \\
\hline $\mathrm{FH}_{10}$ & 0.8933 & 0.8719 & 0.9719 & 0.6016 & 0.9836 \\
\hline $\mathrm{FH}_{11}$ & 0.9268 & 0.9636 & 0.9682 & 0.8329 & 0.9720 \\
\hline $\mathrm{FC}_{1}$ & 0.8751 & 0.9167 & 0.9709 & 0.7173 & 0.9320 \\
\hline $\mathrm{FC}_{2}$ & 0.8834 & 0.9230 & 0.9718 & 0.7437 & 0.9358 \\
\hline $\mathrm{FC}_{3}$ & 0.8154 & 0.8865 & 0.9532 & 0.6100 & 0.9370 \\
\hline $\mathrm{FC}_{4}$ & 0.8092 & 0.8758 & 0.9455 & 0.5911 & 0.9338 \\
\hline $\mathrm{FC}_{5}$ & 0.8332 & 0.9060 & 0.9657 & 0.6092 & 0.9314 \\
\hline $\mathrm{FC}_{6}$ & 0.8427 & 0.9100 & 0.9674 & 0.6252 & 0.9425 \\
\hline $\mathrm{FC}_{7}$ & 0.8559 & 0.9811 & 0.9776 & 0.5814 & 0.9620 \\
\hline $\mathrm{FC}_{8}$ & 0.8518 & 0.9808 & 0.9739 & 0.5769 & 0.9638 \\
\hline $\mathrm{FC}_{9}$ & 0.8461 & 0.9824 & 0.9722 & 0.5456 & 0.9705 \\
\hline $\mathrm{FC}_{10}$ & 0.8325 & 0.9747 & 0.9667 & 0.5421 & 0.9641 \\
\hline $\mathrm{FC}_{11}$ & 0.8601 & 0.9557 & 0.9673 & 0.5931 & 0.9765 \\
\hline $\mathrm{FC}_{12}$ & 0.8642 & 0.9696 & 0.9721 & 0.5744 & 0.9805 \\
\hline
\end{tabular}

On application of two-way ANOVA, a significant difference was observed in the in vitro drug release profiles among the various formulations $\left(\mathrm{FH}_{1}-\mathrm{FH}_{11}\right.$ and $\left.\mathrm{FC}_{1}-\mathrm{FC}_{12}\right)$ at $95 \%$ confidence interval $(\mathrm{p}<0.0001)$. Since, the calculated $\mathrm{F}$ value is much larger than the table value, the null hypothesis of equal population means was rejected and concluded that there is a (statistically) significant difference between the dissolution profiles. This supports the role of polymer type and concentration in controlling the drug release and also indicates the validity of the developed formulations (Table 5). All the calculations were performed using GraphPad Prism v5.1 (GraphPad Prism Software Inc., San Diego, California). 
Table 5. Results of two way ANOVA on the release profiles of ofloxacin from different formulations $\left(\mathrm{FH}_{1}-\mathrm{FH}_{11}\right.$ and $\left.\mathrm{FC}_{1}-\mathrm{FC}_{12}\right)$.

\begin{tabular}{cccccc}
\hline Source of variation & Sum of square & $\begin{array}{c}\text { Degree of } \\
\text { freedom }\end{array}$ & Mean square & Calculated F & Tabulated F \\
\hline Formulations $\left(\mathrm{FH}_{1}-\mathrm{FH}_{11}\right)$ & & & & & 1.91 \\
\hline CSS & 4246 & 10 & 424.6 & 20.08 & 1.96 \\
RSS & 104700 & 9 & 11630 & 550.2 & 1.85 \\
ESS & 1903 & 90 & 21.15 & & 1.90 \\
\hline Formulations $\left(\mathrm{FC}_{1}-\mathrm{FC}_{12}\right)$ & & & & 56.94 & \\
\hline CSS & 23870 & 11 & 2170 & 145.4 & \\
RSS & 55410 & 10 & 5541 & & \\
\hline
\end{tabular}

CSS Column sum of squares, RSS Raw sum of squares, ESS Error sum of squares

\section{CONCLUSION}

The effervescent-based floating drug delivery is a promising approach to achieve in vitro buoyancy by using the gelforming polymer HPMC K4M, carbopol and gas-generating agent sodium bicarbonate. But, addition of crospovidone in the HPMC and carbopol matrices improves the drug release profile. From the swelling and drug release profile it was found that HPMC/carbopol matrices with crospovidone and sodium

Midede kalı̧s süresini uzatan yüzen tabletlerin özelliklerini etkileyen yardımcı maddeler üzerinde bir araştırma

ÖZ

$\mathrm{Bu}$ çalışma kapsamında, yüzen tabletlerin bileşiminde yardımcı madde olarak kullanılan bazı bileşenlerin tabletin mide sıvısının yüzeyinde kalabilme ve ilaç salım özelliklerini nasıl etkilediği araştırılmıştır. Midede kalıss süresini uzatan yüzen tabletler, yaş granülasyon yöntemiyle; hidroksipropilmetilselüloz (HPMC K4M), ilaç salım hızını kontrol eden polimerler-karbopol 934P ve karbopol 971P ve çözünürlüğü arttırıcı olarak krospovidon bicarbonate showed the best release upto $24 \mathrm{~h}$. From the analysis of data, it was found that the drug was diffused out from the tablets. Mechanism of drug release was found to be anomalous non Fickian drug release.

\section{CONFLICT OF INTEREST}

The author(s) confirm that this article content has no conflicts of interest.

kullanılarak hazırlanmıştır. Efervesans etki amacıyla sitrik asit ve sodyum bikarbonat kullanılmıştır. Granülasyon ajanı olarak PVP K30 kullanılmıştır. Formülasyon değişkenlerinin tabletlerin özelliklerine etkileri nicel yöntemlerle; mide sıvısı üzerinde kalabilme özellikleri, şişme özelliği ve ilaç salım özellikleri yönünden incelenmiştir. İlaç salım mekanizması matematiksel modelleme yöntemi kullanılarak çalışılmıştır. HPMC/karbopol matrisi 1:1 oranında kullanıldığında ve krospovidon ile sodyum bikarbonat varlığında elde edilen 24 saatlik ilaç salım profilinin HPMC ya da karbopol’ün tek başına kullanıldığı formülasyonlara kıyasla daha başarılı olduğu tespit edilmiştir. İlaç salım mekanizması ise Fick’e uymayan salım olarak belirlenmiştir.

\section{REFERENCES}

1. Sharma N and Awasthi R. Development and characterization of novel gastroretentive raft forming floating film of atenolol. Indian Drugs 2015; 52: 15-23.

2. Awasthi R and Kulkarni GT. Development of novel gastroretentive drug delivery system of gliclazide: Hollow beads. Drug Dev Ind Pharm 2014; 40: 398-408.

3. Singh BN and Kim KH. Floating drug delivery systems: an approach to oral controlled drug delivery via gastric retention. J Control Release 2000; 63: 235-9.

4. Awasthi R and Kulkarni GT. Decades of research in drug targeting to the upper gastrointestinal tract using gastroretention technology: Where do we stand?. Drug Deliv 2016; 23: 378-94.

5. Okeri HA and Arhewoh IM. Analytical profile of the fluoroquinolone antibacterials ofloxacin. African J Biotechnol 2008; 7: 670-80.

6. Sangekar S, Vadino WA, Chaudry I, Parr A, Beihn R, Digenis G. Evaluation of the effect of food and specific gravity of tablets on gastric retention time. Int J Pharm 1987; 35: 187-91. 
7. Kiran MK, Shah MH, Ketkar A, Mahadik KR, Paradkar A. Effect of drug solubility and different excipients on floating behavior and release from glyceryl monooleate matrices. Int J Pharm 2004; 272: 151-60.

8. Srivastava AK, Wadhwa S, Ridhurkar D, Mishra B. Oral sustained delivery of atenolol from floating matrix tablets - formulation and in vitro evaluation. Drug Dev Ind Pharm 2005; 31: 367-74.

9. Fukuda M, Peppas NA, McGinity JW. Floating hot-melt extruded tablets for gastroretentive controlled drug release system. J Control Release 2006; 115: 121-9.

10. Costa P and Lobo JMS. Modeling and comparison of dissolution profiles. Eur J Pharm Sci 2001; 13: 123-33.

11. Kavanagh $\mathrm{N}$ and Corrigan OI. Swelling and erosion properties of hydroxypropyl methylcellulose (Hypromellose) matrices: Influence of agitation and dissolution medium composition. Int J Pharm 2004; 279: 141-52.

12. Jamzad S, Tutunji L, Fassihi R. Analysis of macromolecular changes and drug release from hydrophilic matrix systems. Int J Pharm 2005; 292: 75-85.
13. Patel VF and Patel NM. Statistical evaluation of influence of viscosity and content of polymer on Dipyridamole release from floating matrix tablets: A technical note. AAPS PharmSciTech 2007; 8 (69): E1-E6.

14. Chavanpatil M, Jain P, Chaudhari S, Shear R, Vavia P. Novel sustained release, swellable and bioadhesive gastroretentive drug delivery system for ofloxacin. Int J Pharm 2006; 316: 86-92.

15. Siepmann J and Peppas NA. Modeling of drug release from delivery systems based on hydroxypropyl methylcellulose (HPMC). Adv Drug Deliv Rev 2001; 48: 139-57.

16. Higuchi T. Mechanism of sustained action medication. Theoretical analysis of rate of release of solid drugs dispersed in solid matrices. J Pharm Sci 1963; 52: 1145-9.

17. Khan F, Razzak Md SMI, Khan Md ZR, Azad Md AK, Chowdhury JA, Reza Md S. Theophylline loaded gastroretentive floating tablets based on hydrophilic polymers: preparation and in vitro evaluation Pak J Pharm Sci 2009; 22: 155-61. 